\title{
Effect of Freeze-drying and Oven-drying Methods on Flavonoids Content in two Romanian Grape Varieties
}

\author{
LACRAMIOARA OPRICA ${ }^{1 *}$, RADU GHEORGHE ANTOHE ${ }^{2}$, ANDREEA VERDES ${ }^{3}$, MARIUS NICUSOR GRIGORE ${ }^{1}$ \\ ${ }^{1}$ Alexandru Ioan Cuza University, Faculty of Biology, 11 Carol I Blvd., 700506, lasi, Romania \\ ${ }^{2}$ Bucharest Academy of Economics Studies, 6 Romana Sq., 010374, Bucharest, Romania \\ ${ }^{3}$ Alexandru Ioan Cuza University, Faculty of Physics, 11 Carol I Blvd., 700506, Iasi, Romania
}

\begin{abstract}
The aims of this work was to investigate the effect of thermal drying method (vacuum oven drying), and nonthermal drying method (freeze drying) on the flavonoids content in two red grape varieties (Cabernet Sauvignon and Merlot) from different grape components (seed, skin, and pulp) collected from two experimental fields, Bucium and Copou (North East of Romania). In general, the fresh skin of Cabernet and Merlot varieties has the highest flavonoids content followed by those obtained by oven-drying and freezedrying process. A similar situation was observed in the other component of grape varieties like pulp and seeds meaning in the way that the flavonoid content in oven-dried samples were higher than that in the freeze-dried samples. In addition, from both varieties, Merlot collected from Bucium presented the highest content compared with Cabernet.
\end{abstract}

Keywords: freeze-drying and oven-drying, flavonoids, Cabernet Sauvignon and Merlot grape varieties

Grape (Vitis vinifera L.) is the primary grape species cultivated for wine production, with an industry valued annually in the billions of dollars worldwide. The grapes are not only delicious but they are considered to be the second most important fruit crop after citrus as a significant source of antioxidants from fruit species in the world [1].

Secondary metabolites of plant play a main role in both human and animal health. Within these, flavonoids are natural substances that are present in vegetables and fruits and are valuable components of animal and human diet [2]. Flavonoids are phenolic phytocompounds, which are very important determinants in the nutritional and sensory quality of fruits and vegetables. Flavonoids are low molecular weight compounds and can be classified into six major classes: anthocyanins, flavones, isoflavones, flavanones, flavonols, and flavanols [3,4]. Beneficial effect of flavonoids present in plants is to help for decrease oxidative stress by scavenging reactive oxygen species because of their antioxidant activity and thus prevent cell damage $[5,6]$. The grape berry is characterized by a wide variety of phytocompounds, most of which have been demonstrated to have therapeutic or health promoting properties. Thus, consumption of flavonoid-rich grape products may have a significant beneficial effect on human health such as brain function, obesity and diabetes, hepatoprotective activity, cardiovascular diseases and cancer prevention [7]. Meanwhile, grape flavonoids have antioxidant activity [8], antimicrobial and anti-viral activity [9] as well as anti-inflammatory action [10]. Moreover, the flavonoids from purple grape juice and red wine may inhibit the initiation of atherosclerosis [11]. The amount of flavonoids in red wine depends on the grape variety, cultivation area, sun exposure, wine-making technique and wine age [12]. Flavonoid compounds were asymmetrically distributed in the skin, pulp and seeds [13].

Grape seed powder is a natural agricultural by-product of grapes and has a high concentration of vitamin $E$, flavonoids, linoleic acid and oligomeric proanthocyanidins [14]. Moreover, grape seeds and skin are good sources of phytochemicals such as gallic acid, catechin and epicatechin, which are suitable raw materials for production of antioxidant dietary supplements [15]. On the other hand, supplementing broiler diet with grape pomace increased the antioxidant activity in the diet and ileal contents but did not adversely affect growth performance or protein and amino acid digestibility. In addition, grape pomace in broiler diet reduced lipid oxidation of meat during refrigerated storage [16] thus increasing its shelf-life.

Because the plant parts (such as seeds, fruit skin or peel, bark and flower) are rich in flavonoids and the antioxidant capacity of meat is very low, this can be increased by adding during processing flavonoids in meat as raw or in extract form without comprising the sensory attributes of meat and meat products. Thus, in this respect, grape seed extracts have been used in meat industry to enhance the antioxidant capacity of meat [17].

Because of some active compounds, such as, dietary fiber, polyphenols, flavonols, and resveratrol grape skin it is commonly used as a nutritional supplement In addition, grape skin flour may be used as a functional ingredient in the bakery products industry, from both chemical and rheological point of view [18].

Drying or dehydration is an ancient process used to preserve and prolong shelf life of various food products as well as with the purpose of obtaining a solid product sufficiently low in water content [19]. The main aim of drying food products is to remove water in the solid to a level at which microbial spoilage and deterioration resulting from chemical reactions is significantly reduced $[20,21]$.

There are two types of drying, which includes natural and mechanical drying. Natural drying is the method of drying, in which the natural source is used; it is also known as sun/solar drying. Various types of mechanical drying system are available like hot air-drying, freeze-drying, oven drying, vacuum-drying, fluidized bed drying, spray-drying etc. Generally, air-drying and oven drying are favoured due to processing cost and efficiency. By far, freeze drying is regarded as the better method for moisture removal, with final products of the highest quality compared with airdrying [22].

*email: lacramioara.oprica@uaic.ro; Phone:0765116878 
World-wide, Romanian red wines enjoy a superior appreciation and solicitation to white wines, due to the four quality grape varieties predominant in our vineyards: Feteasca neagra, Merlot, Cabernet Sauvignon and PinotNoir [23].

In view of the possible use in food and pharmaceutical industry or as feed ingredients of grapes antioxidants, in present study the effect of thermal drying method (ovendrying), and nonthermal drying method (freeze-drying) on the flavonoids content in two red grape varieties (Cabernet Sauvignon and Merlot) from different grape components (seed, skin, and pulp) collected from two experimental fields, Bucium and Copou (North East of Romania) has been investigated.

\section{Experimental part}

\section{Materials and methods}

Sample

In this research, the CabernetSauvignon and Merlot (Vitis vinifera L.) grape varieties from two experimental fields (October 2015 vintage) Bucium and Copou (North East of Romania) were used. Different parts of grape (seed, skin epicarp, and pulp - mesocarp) of fully ripened and matured berry were separated into three groups. One was represented by the fresh sample and the others were dried in an oven and a freeze-dryer, respectively. Meanwhile, freshly samples of the grape parts (seed, skin, and pulp) varieties were maintained in a plastic container and refrigerated at $4^{\circ} \mathrm{C}$ for 1 day.

\section{Thermal and nonthermal drying methods}

Oven-drying process was performed using the oven where dry weight of the berry parts was determined after drying at a temperature of $110^{\circ} \mathrm{C}$ for three days (until weight stability) [24]. For freeze-drying process, the berry components were frozen for $24 \mathrm{~h}\left(\mathrm{at}-80^{\circ} \mathrm{C}\right)$, homogenized with food processor and put into freeze-dryer (ChristRIPHR 2-4 plus). The trial lasted from 12 to 24 (48) h, under conditions of low temperature and high vacuum.

The flavonoids content was measured following a spectrophotometric method [25]. Briefly, methanol extract was appropriately diluted with distilled water. Initially, 5\% $\mathrm{NaNO}_{2}$ solution was added to each test tube; after five minutes, $10 \% \mathrm{AlCl}_{3}$ solution was added and then at six $\min 1.0 \mathrm{M} \mathrm{NaOH}$ was added. Finally, water was then added to the test tube and mixed well. Absorbance of resulting pink-colored solution was read at $510 \mathrm{~nm}$ against the blank (distilled water). Total flavonoids content was expressed as mg catechin equivalent, depending on the fresh weight (mg CE/g FW), dry weight (mg CE/g DW) or lyophilized weight $(\mathrm{mg} \mathrm{CE} / \mathrm{g} \mathrm{LW})\left(\mathrm{R}^{2}=0.98\right)$. Three readings were taken for each sample and the result averaged.

\section{Results and discussions}

Flavonoids are a group of low molecular weight compounds with high antioxidant properties. The specific chemical structure allows them to reduce oxidative stress through numerous mechanisms [26,27]. In vivo research has also demonstrated that flavonoids can act as indirect antioxidants through the antioxidant defense system and increased uric acid plasma concentration [28-30].

Consumption of dietary flavonoids derived from grapes, in the form of grape extracts and grain seed pow ders, has been shown to effectively suppress oxidative stress and prevent in vivo oxidative degradation. Such activities are attributed to various functions of grapevine flavonoids as free radicals and metal chelating agents [31-33].
Recently, it has been found that the by-products, even those obtained as a result of the processing of grapes (grape marc, seeds, skin, grain oil), have high nutritional value and have been marketed in various forms of powders, granules, various concentrated or dried extracts.. It is worth noting that these products have effects on the health of the body (brain function, obesity and diabetes, hepatoprotective activity, hepatoprotective disease, cancer prevention) [34].

In the fresh skin of the two varieties a higher content of flavonoid content in the Merlot variety ( $3.45 \mathrm{mg} \mathrm{CE} / \mathrm{g} \mathrm{FW}$ and $3.92 \mathrm{mg}$ CE/g FW) compared to Cabernet variety was found ( $1.23 \mathrm{mg} \mathrm{CE} / \mathrm{g} \mathrm{FW}$ and $1.70 \mathrm{mg} \mathrm{mg} \mathrm{CE} / \mathrm{g} \mathrm{FW}$ ) (fig. 1 ). Regarding the harvesting site, it was observed that at Bucium the content of this secondary metabolite was higher for both studied varieties.
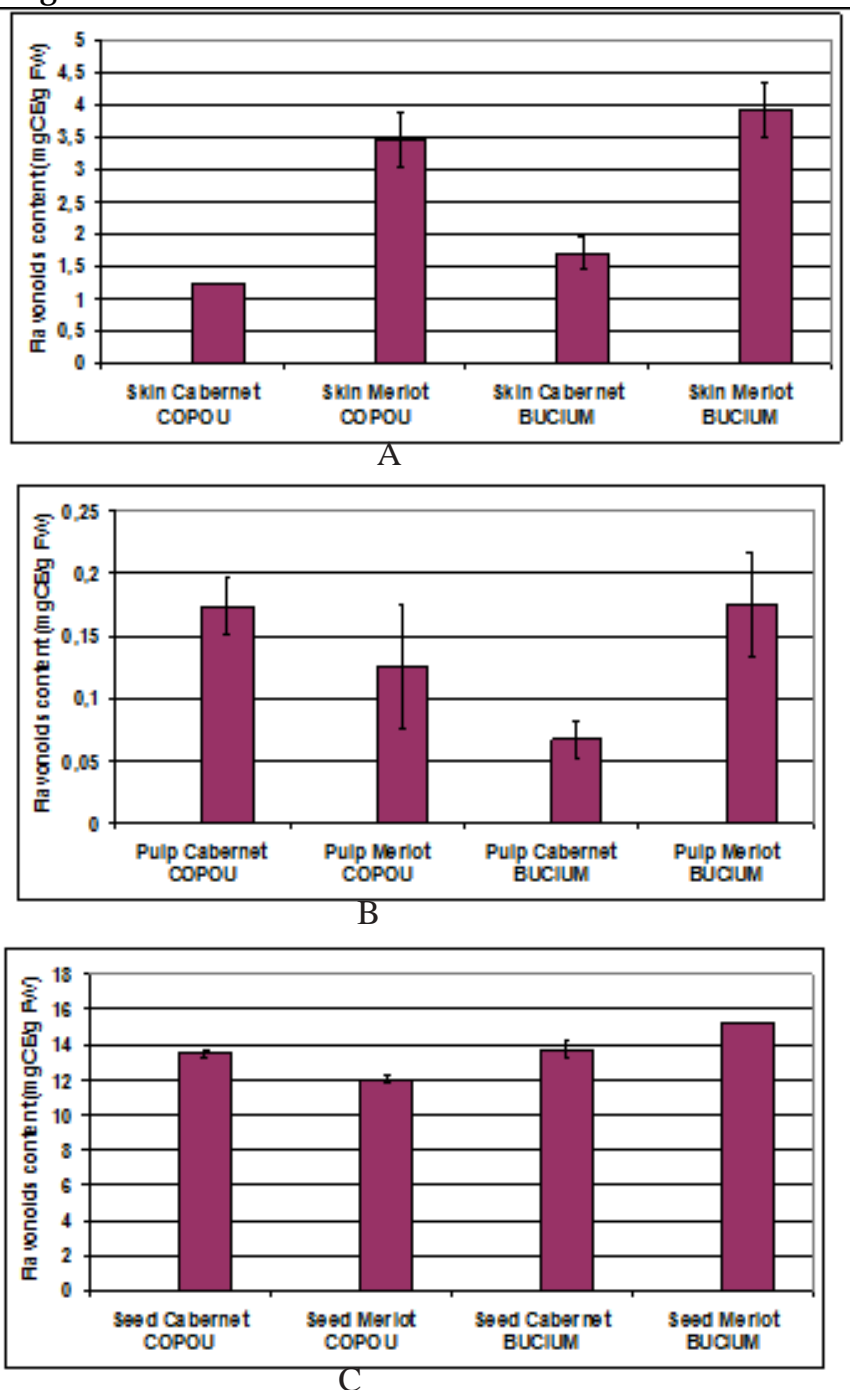

Fig 1. Flavonoids content in fresh components of Cabernet Sauvignon and Merlot grapes varieties (A-skin, B-pulp, C-seeds)

In the Cabernet variety, the flavonoid content in the fresh pulp varied between $0.066 \mathrm{mg} \mathrm{CE} / \mathrm{g} \mathrm{FW}$ (Bucium location) and $0.17 \mathrm{mg} \mathrm{CE} / \mathrm{g} \mathrm{FW}$ (Copou location). Very close values were noted in the Merlotharvested from Copou and Bucium, $0.12 \mathrm{mg} \mathrm{CE} / \mathrm{g} \mathrm{FW}$ and $0.17 \mathrm{mg} \mathrm{CE} / \mathrm{g} \mathrm{FW}$, respectively.

The content of flavonoids in the fresh seeds of the grape varieties studied was relatively close in the abundance locations ranging between 12.02 and $15.25 \mathrm{mg} \mathrm{CE} / \mathrm{g} \mathrm{FW}$, both values being for the Merlotvariety (Copou and Bucium, respectively)

From the analysis of figure 2, it appears that in the two grape varieties, the flavonoid content, analyzed on dry components, varies in the following way: the highest 

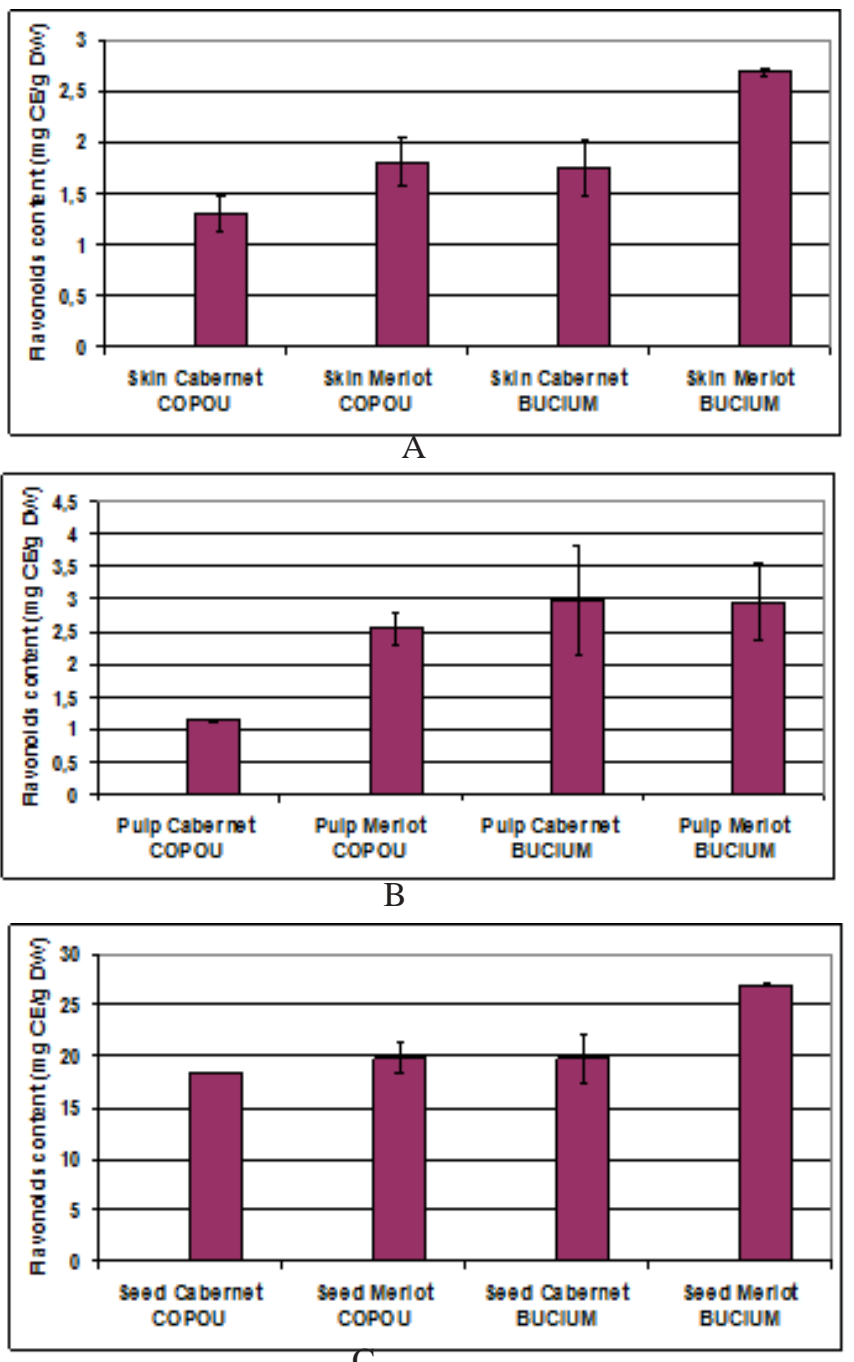

Fig 2. Flavonoids content in oven-dried components of Cabernet Sauvignon and Merlot grapes varieties (A-skin, B-pulp, C-seeds)

content was recorded for the seeds, followed by the skin and finally the pulp.

In the case of the skin, a slightly higher content was found for Merlot, a situation valid for both collection points (Bucium - $2.68 \mathrm{mg} \mathrm{CE} / \mathrm{g} \mathrm{DW}$ and Copou - $1.79 \mathrm{mg} \mathrm{CE} / \mathrm{g}$ DW). For Cabernet variety, a higher value was recorded for the Bucium harvesting site ( $1.74 \mathrm{mg} C E / \mathrm{gDW}$ ) compared to Copou (1.30 mg CE/g DW).

In the pulp, only for the Cabernet variety from Copou, there was a lower value of the flavonoid content $(1.14 \mathrm{mg}$ CE/g DW); for the Merlot variety (both locations) and for Cabernet in Bucium, the values were higher, but without significant differences between them.

Regarding the seeds, the flavonoid content varied between $18.32 \mathrm{mg} \mathrm{CE} / \mathrm{g}$ DW and $26.97 \mathrm{mg} \mathrm{CE} / \mathrm{g}$ DW in Cabernet collected from Copou and Merlot, respectively, collected from Bucium. The flavonoid content was relatively the same for Cabernet (Copou and Bucium) seeds and Cabernet grape seeds collected from Bucium but slightly higher for the Merlot variety collected from Bucium.

Regarding the two stations where the biological material was collected, it was found that both varieties had a higher flavonoid content in the three components ( skin, pulp and seeds) in the Bucium resort compared to Copou.

In a similar study, Oprica et al. (2016) [3] found for the other varieties investigated (Grasa de Cotnari, Feteasca and Tamaioasa) that the highest values for flavonoids were recorded in the case of seeds followed by skin and pulp.
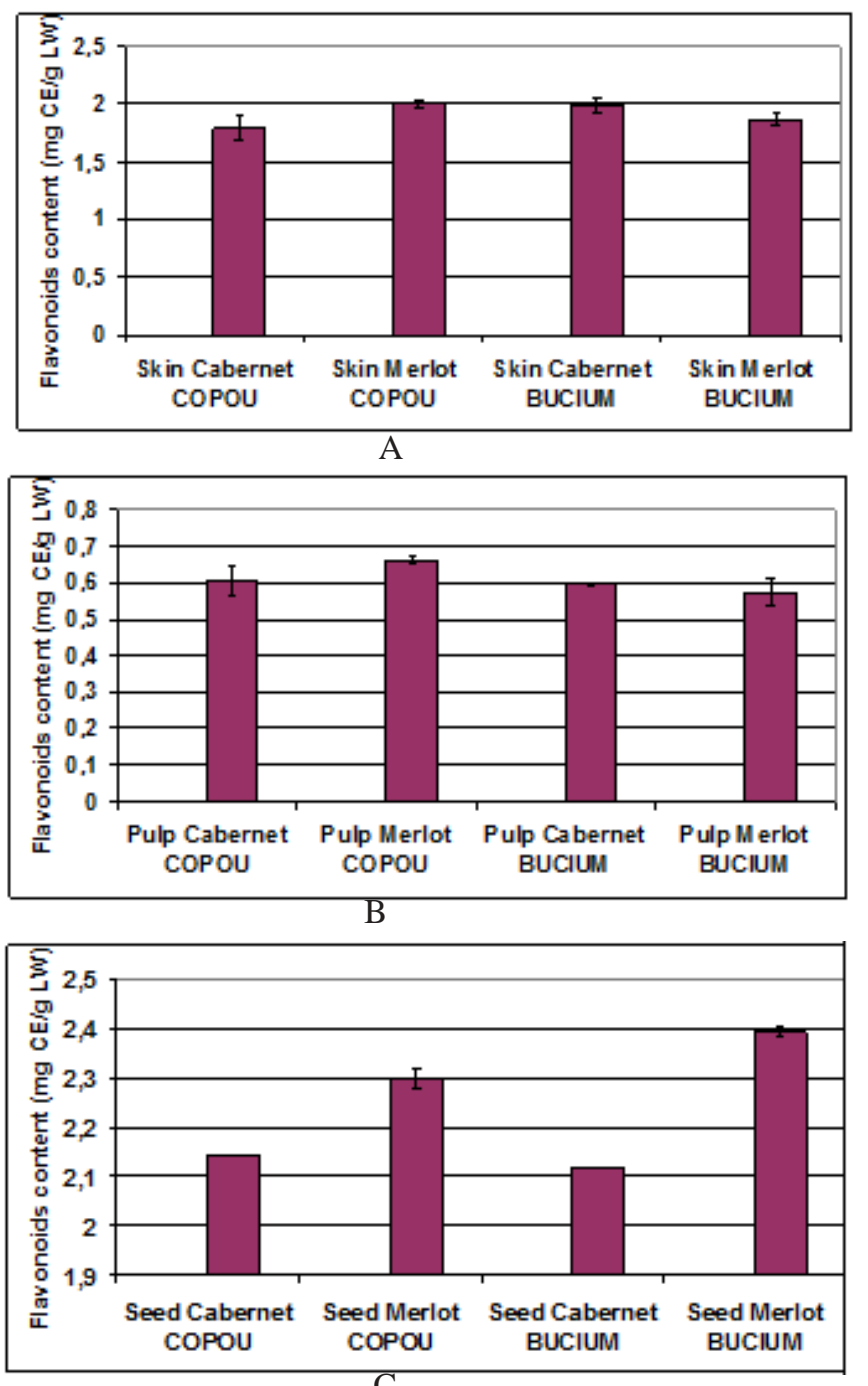

Fig 3. Flavonoids content in freeze-dried components of Cabernet Sauvignon and Merlot grapes varieties (A-skin, B-pulp, C-seeds)

In general, the flavonoid composition of grape varieties seems to vary greatly depending on their genetic origin, fruit harvesting period and fruit components (skin and edible parts) [35]. The presence and/or concentration of flavonoids may be influenced by differences in varieties, agricultural practices, test protocols [36] as well as exposure to sunlight and temperature [37].

Phenolic substances in grapes are over $10 \%$ in the pulp, $60-70 \%$ in seeds and $28-35 \%$ in the skin. Catechin and epicatechin are very important in grape seed and, according to a research of lacopini et al. (2008) [38], Merlot varieties (138.8 and $141.8 \mathrm{mg} / 100 \mathrm{~g}$ seeds) and Cabernet Sauvignon (131.8 and $127.6 \mathrm{mg} / 100 \mathrm{~g}$ seed) indicate a high level of catechin and epicatechin in seed extracts.

In the case of total flavonoid content studied on lyophilized material, the above described pattern is only partially maintained. Thus, in the case of the skin, the Merlot variety has a higher value only for that collected in Copou, which is also found in the pulp (fig. 3). Both in the skin and in the pulp, the flavonoid content has very similar values to both studied varieties, even if they are collected from different locations.

The content of flavonoids in the lyophilized seeds was slightly higher in Copou (2.14 mg CE/g LW) compared to Bucium ( $2.11 \mathrm{mg} \mathrm{CE} / \mathrm{g} \mathrm{LW}$ ). In the Merlot variety, the flask content was higher at the Bucium site $(2.29 \mathrm{mg}$ CE/g LW $)$.

In plant, the freeze drying method has high efficiency in moisture removal and maintains bioactive components, 
including the antioxidant compounds [39]. The lower the moisture content and the greater the rupture of the cell structure may lead to higher solvent extraction efficiency of antioxidant compounds [40, 41].

In general, the content of flavonoids content in ovendried samples was higher than that in the freeze-dried samples. These results are not in concordance with those obtained by Rabeta and Lin (2015) [42] who studied the same drying methods on antioxidant activities (including flavonoids) of leaves and berries of Cayratia trifolia.

\section{Conclusions}

To summarize, there was a great variability in the content of flavonoids compounds in the grape skin, pulp and seeds of the Cabernet Sauvignon and Merlot grape varieties collected from both experimental locations regarding the effect of thermal drying method (vacuum oven drying), and nonthermal drying method (freeze drying). Thus, in the skin the flavonoid content, although different depending on varieties, was the highest in the fresh material followed by those freeze-dried and then the oven-dried. On the other hand, both in the pulp and in the seeds of the grape varieties which have been dehydrated by drying and lyophilization, it has been obtained the highest flavonoid content.

Freeze-dried pulps of studied grape varieties exhibited higher flavonoids content than fresh pulp. The situation is reversed in seeds, in the sense that fresh seeds grape varieties contained higher flavonoids content compared to those obtained from freeze-drying process.

\section{References}

1. PIRINCCIOGLU, M., KIZIL, G.M., KIZIL., OZDEMIR, G., KANAY, Z., KETANI, M.A., J. Food Funct., 3, 2012, p. 668.

2. DABBOU, S., GASCO, L., ROTOLO, L., POZZO, L., TONG, J.M., DONG, X.F., RUBIOLO, P., SCHIAVONE, A., GAl, F., Asian Australas. Anim. Sci., 31(2), 2018, p. 270.

3. OPRICA, L., VEZETEU, G., GRIGORE, M.N., Iran J. Public Health, 45 (6), 2016, p.826.

4. JARA-PALACIOS, M.J., HERNANZ, D., ESCUDERO-GILETE, M.L., HEREDIA, F. J., Molecules, 21, 2016, p.1526.

5. SABU, M.C., SMITHA, K., KUTTAN, R. J. Ethnopharmacol., 83, 2002, p. 109.

6. LEAN, M.E., NOROOZI, M., KELLY, I., BURNS, J., TALWAR, D., SATTAR, N., CROZIER, A. Diabetes, 48, 1999, p. 176.

7. GEORGIEV, V., ANANGA, A., TSOLOVA, V., Nutrients, 6(1), 2014, p. 391.

8. LAKSHMI B,V.S., SUDHAKAR, M., APARNA, M., Environ. Toxicol. Pharmacol., 35, 2013, p. 361.

9. PAPADOPOULOU, C., SOULTI, K., ROUSSIS, I.G, Food Technol. Biotechnol., 43, 2005, p. 41.

10. LI, W.G., ZHANG, X.Y., WU, Y.J ., TIAN, X., Acta Pharmacol. Sin. 22, 2001, p. 1117.

11. FOLTS, J.D., Adv. Exp. Med. Biol., 505, 2002, p.95.

12. ARAUJ O, P.F., NITZKE, J.A., KLIPEL, C.B., VOGT DE J ONG, E., Food Chem., 120, 2010, p. 109.

13. CHEN, W.K., Y. WANG, X.T. GAO, X.H. YANG, F. HE, C.Q. DUAN, J. WANG, Aust. Soc.Vit. Oen., 24(3), 2018, p. 379.
14. ABU HAFSA, S. H., S. A. IBRAHIM, J. Anim. Physiol. Anim. Nutr., 102 (1), 2018, p. 268.

15. YILMAZ, YUSUF, ROMEO, T. TOLEDO, J. Agric. Food Chem.., 52 (2), 2004, p. 255.

16. BRENES, A, VIVEROS, A, GONI, I, CENTENO, C, SÁYAGO-AYERDY, SG, ARIJA, I, SAURA-CALIXTO, F., Poult. Sci., 87(2), 2008, p. 307.

17. KUMAR, P.N, KUMAR, S., TRIPATHI, M.K., MEHTA, N., RANJ AN, R., BHAT, Z.F., SINGH, P.K., Vet. World 6(8), 2013, p. 573.

18. OPREA, O.B., APOSTOL, L. , BUNGAU, S., CIOCA, G., SAMUEL, A.D. , BADEA, M., GACEU, L., Rev. Chim. (Bucharest), 69, no. 1, 2018, p.70

19. RATTI, C., J. Food Eng., 49, 2001, p. 311.

20. TANG, W., ZHANG, M., ADHIKARI, B., MUJUMDAR, A.S., Drying Technol., 31, 2013, p. 13.

21. CHIEWCHAN, N., MUJUMDAR, A.S., DEVAHASTIN, S., Drying Technol., 33, 2015, p. 1700.

22. KORUS, A. LWT, Food Sci. Technol., 44, 2011, p. 1711.

23. IGNAT, G., BALAN, G., SANDU, I., COSTULEANU, C.L., SANDU, VILLE, S.T., Rev.Chim.(Bucharest), 67, no. 8, 2016, p.1560.

24. GONZALEZ, L., GONZALEZ-VILAR, M. Determination of relative water concentration. Handbook of plant ecophysiology techniques. Netherlands: Kluwer Academic Publishers, 2003, p. 207.

25.DEWANTO, V., WU, X., ADOM, K.K., LIU, R.H., J. Agric. Food Chem. 50, 2002, p. 3010.

26. RAJ, N.K., SRIPAL, R.M., CHALUVADI, M.R., KRISHNA, D.R., Indian J. Pharmacol., 33, 2001, p. 2.

27. PROCHAZKOVA, D., BOUSOVA, I., WILHELMOVÁ, N., Fitoterapia., 82, 2011, p. 513.

28. CAROCHO, M., FERREIRA, I.C.F.R., Food Chem. Toxicol., 51, 2013, p. 15.

29. KHLEBNIKOV, A.I., SCHEPETKIN, I.A., DOMINA, N.G., KIRPOTINA, L.N., QUINN, M.T., Bioorg. Med. Chem., 15, 2007, p. 1749.

30. PIETTA, P.G., J. Nat. Prod., 63, 2000, p.1035.

31. CHOI, S. K., ZHANG, X. H., SEO, J. S., Nutr. Res. Pract., 6, 2012, p.3. 32. LAKSHMI, B.V.S., SUDHAKAR, M., APARNA, M., Environ. Toxicol. Pharmacol., 35, 2013, p.361.

33. SCOLA, G., SCHEFFEL, T., GAMBATO, G., FREITAS, S., DANI, C., FUNCHAL, C., GOMEZ, R., COITINHO, A., SALVADOR, M., Neurosci. Lett., 534, 2013, p.145.

34. GEORGIEV, V., ANANGA A., TSOLOVA V., Nutrients, 6(1), 2014, p. 391.

35. LU, Y., ZHANG, C., BUCHELI P., WEl, D., Plant Foods Hum. Nutr, 61, 2006, p. 57.

36. KIM, D.O., JEONG, S.W., LEE, C.Y., Food Chem., 81, 2003, p. 321. 37. MAKRIS, D.P., KALLITHRAKA, S., KEFALAS, P., J. Food Compost. Anal., 19, 2006, p. 396.

38. IACOPINI, P., BALDI, M., STORCHI, P. SEBASTIANI, L. J. Food Compost. Anal., 21, 2008, p. 589.

39. KROKIDA, M.K., PHILIPPOPOULOS, C., J. Food Eng., 73, 2006, p. 135.

40. HOSSAIN, M.B., BARRY-RYAN, C., MARTIN-DIANA, A.B., BRUNTON, N.P. Food Chem., 1, 2010, p. 85.

41. SHIH, M.C., KUO, C.C., CHIANG, W.C. Food Chem., 117, 2009, p.114.

42. RABETA, M.S., LIN, S.P., Sains Malays., 44(2), 2015, p. 275.

Manuscript received: 03.08 .2018 